INDEPENDENT JOURNAL OF MANAGEMENT \& PRODUCTION (IJM\&P)

http://www.ijmp.jor.br

v. 12, n. 4, May-June 2021

ISSN: 2236-269X

DOI: 10.14807/ijmp.v12i4.1332

\title{
SERVICE VALUE STREAM MANAGEMENT (SVSM) - A CASE
}

STUDY

Delmo Alves de Moura

Federal University of $A B C$, Brazil

E-mail:delmo.moura@ufabc.edu.br

Victor Carneiro Bonadio

Federal University of $A B C$, Brazil

E-mail:vbonadio@gmail.com

Submission: 4/7/2020

Revision: 6/3/2020

Accept: 8/7/2020

\section{ABSTRACT}

Air transport accounts for a significant portion of all wealth production in the world. In the case of Brazil, although the air transport industry is undergoing profound changes because of the economic crisis, there is enormous potential for this market to resume growth, especially when compared to the number of passengers/inhabitant of already consolidated markets, such as the United States. However, to grow in this market, airlines need to be prepared to adapt to new dynamics and overcome the effects of the economy on the industry. This paper presents a case study of an airline that in the crisis period lost its market leadership and chose to restructure the business-to-business (B2B) sales department to achieve better results in its Business Process Management (BPM). It seeks to identify which factors led the company to lose this leadership from the perspective of its customers and propose a way to review internal processes, eliminating waste, so that the company can resume its position in the market. It has been applied lean service-focused concepts to raise possible causes, identifying and optimized internal sales department flows to create a more appropriate customer value proposition, and correcting for each type of waste mapped. The objective of this case study was to apply the concepts related to the Value Stream Map tool to reduce activities that do not add value, in a service area, of a large airline. The objective was to improve the company's Business Process Management, aiming at a lean, effective and efficient process, improving the organization's performance and competitiveness. 
DOI: $10.14807 /$ ijmp.v12i4.1332

Keywords: Value Stream Map; Business Process Management; Business-to-Business; Lean; Waste

\section{INTRODUCTION}

The globalized economy and new technological advances have changed market dynamics by requiring product or service providers to seek to improve their operational effectiveness and market positioning. In this context the market has been adapting, moving from be centered on the product or service to being centered on the value proposition offered to the customer. Thus, companies seek to adapt to new market dynamics and gain competitive advantages over their competitors (Bose, 2002).

According to Rich (2000), one of the most significant points in the development of new market practices is directly related to the way organizations relate to their customers. Xu and Walton (2005) explain that customer knowledge acquisition is a strategic tool to gain competitive advantages in the modern market. Thus, market developments require companies to employ new ways of knowing their customers and then identifying their real needs and providing them with the exact solutions without directly affecting the company's costs.

In many situations companies themselves may also behave as buyers/consumers, since they need to purchase products and services, this relationship is known as Business-to-Business (B2B). According to Kaplan and Sawhney (2000), companies need to acquire inputs for their production processes and services for the continuity of their operations. For Wynstra et al., (2006) when companies need to provide services from other companies, the customer figure represents two parts, one of them is the consumer customer representing the other business, such as buyers and the other is user customers, in this case the employee who will ultimately use the purchased product or service.

According to Hines et al. (1998), customer value is created in two ways, the first is when waste is reduced and costly activities are eliminated, while the second is value creation, that is, when features or services (valued by customers) are presented and offered additionally to the customer. BPM must be orientated to their business processes on the customer (Ferreira et al., 2018). Such characteristics can also be found within Lean thinking. Lean thinking was born on the factory floor of the Japanese auto industry in the 1980s. Its concepts have evolved, and today they seek to create noticeable customer value by adding features to products and services and removing non-value-added activities (Akdağ et al., 2017; Cavdur et al., 2019). 
Despite this new trend, Woo and Ennew (2004) state that within B2B relationships quality in customer relationships remains underexplored by companies. According to Caceres and Paparoidamis (2007), developing and sustaining a customer loyalty relationship in B2B is still a difficult point to reach. For Zoltners et al. (2008), the sales force is one of the most relevant areas for companies, as this is the area that establishes direct relationships with customers, which ultimately is directly related to the performance of the organization as a whole, and therefore , considered a strategic area for companies (Zelt et al., 2018).

In order to fill this gap, this paper raises the following questions: Is it possible to use lean tools to optimize existing processes in the sales area of a service company? What are the possible sources of waste found in companies that adopt the B2B sales model, and what can be done to avoid them from their customer's perspective?

This paper adopts a case study-based methodology to map organizational structures focused on the sales sector of a company that has as one of its main sources of revenue B2B sales, in which the value stream map methodology is applied to improve operating processes in the company and add value to the B2B customer.

The flow map is one of the tools that emerged with the evolution of lean concepts, it was gradually being introduced in several different areas of the productive sector, seeking to redefine and redesign processes that lead to waste reduction. For Barber and Tietje (2013) the entire sales process involves the co-creation of value between sellers and customers and explores how the sales process can be mapped and analyzed by applying the value stream map (Cavdur et al., 2019).

\section{LITERATURE REVIEW}

Analyzing how different market structures relate to two English-language acronyms are easily found in the literature, B2B and B2C. Gummesson and Polese (2009) propose that the letter B identifies different types of business, and that depending on the positioning of the business within the relationship, it can represent both a supplier and a customer. Håkansson et al. (2009), explain that in a B2B relationship there may be different actors who interact in different ways, for Mikolon et al. (2015) different actors may have different goals and perceptions, depending on their role in this relationship. Wynstra et al. (2006) also include service providers in B2B relationships and highlight the role of actors as salespeople, responsible for selling and delivering what they are offering, and for customers who can be viewed in two different ways: 
DOI: $10.14807 /$ ijmp.v12i4.1332

- Sales Business (Bs): Represent a company's sales area.

- Customer (Bc): Represent the other business such as buyers, managers, and members of the governing body of organizations.

- User Client (U): Customers who will use the service, as shown in Figure 1.

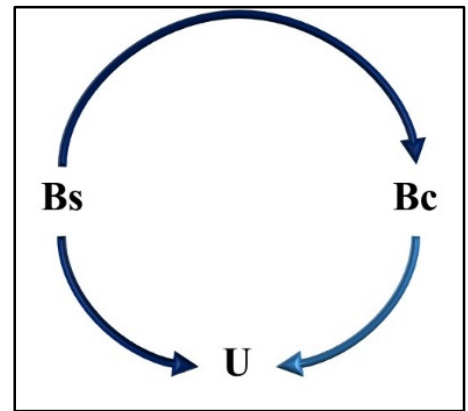

Figure 1: Customer vs. Consumer User

Ulaga and Eggert (2006) pointed out that in the last decades B2B markets have been marked by the tendency to create closer relationships between sellers and customers, but with the involvement of a smaller number of actors. Leonidou (2004) points out that long-term relationship establishments collaborate to create a mutual benefit for sellers and customers. According to Zolkiewsk et al. (2017), the B2B relationship can also present an experience that creates customer value. Understanding what makes the B2B relationship long and stable is considered by Caceres and Paparoidamis (2007) as one of the central points of academic interest in the study of relationships between organizations.

The global economy is a complex and dynamic system that requires better responsiveness of companies. Cronin and Taylor (1992) consider not only the quality of products and services, but also customer satisfaction as the main factors for companies to achieve competitive sustainability in the market. Given this importance, many companies are changing their market positioning to become customer oriented and, in this context, the search for their satisfaction has become increasingly challenging. In this sense, the relationship between company and customer becomes an important source of information to understand customer needs (Khosravi, 2016).

In this way, companies seek to acquire knowledge by interacting and dialoguing with their customers, in order to understand their current and future real needs and preferences. In order to offer services and products adjusted to expectations, creating a long-term relationship and greater loyalty between companies and their customers and clients (Lee et al., 2011; Gibbert et al., 2002; Mithas et al., 2005; Gębczyńska, 2016). 
DOI: 10.14807/ijmp.v12i4.1332

The stresses that the isolation of companies imposes difficulties for developing skills required by the modern world, in which they are exposed to a high diversity of customers, technologies and suppliers. Relationships in a structured, interconnected and interactive system increase the technological and managerial skills needed to improve products, processes and services. As access to knowledge and the ability to build learning relationships can be determining factors for the survival and success of companies.

For this, according to $\mathrm{Wu}$ (2014), companies are establishing channels to acquire more knowledge, thus improving the relationship with the customer. Thus, arise the need to manage the information from this relationship, to transform the data obtained into improving the quality of the services customer (Khodakarami \& Chan, 2014; Li \& Calantone, 1998).

\section{LEAN EVOLUTION}

In this part of the literature review, the focus is to demonstrate, over time, the application of the Lean technique to the service area, as the origin of the technique was the manufacturing area.

The use of lean thinking has had significant impacts on both academia and industry cycles in recent decades. According to Shingo (1981), Monden (1983) and Ohno (1988), lean thinking originated on the factory floor of Japanese industries, especially in the resourceconstrained auto industry and a very competitive market.

In this context, innovations in operations management have emerged as such as the justin-time (Kanban) production system with a focus on on-demand production aimed at eliminating process waste. In 1950, these new techniques were applied mainly in engine manufacturing, later in 1960 the same concepts were used in vehicle assembly lines, but it was only in 1970 when the concepts were applied throughout the supply chain and which began to spread lean (Hines et al., 2004; Thomas, 2018; Balocco et al., 2019; Cavdur et al., 2019).

According to Womack and Jones (1996), it was only after the 1990s, accelerated by the promotion of success stories from various sectors, that Western organizations adapted their production systems based on lean principles, and then a diffusion of "production" lean "off the shop floor. These principles involved identifying customer value, managing value streams, and striving to reduce all forms of waste to zero, including in the service industry. Abdi et al. (2006) presented five principles in the lean approach from a service perspective:

a) Specify value per service. 
DOI: 10.14807/ijmp.v12i4.1332

b) Understand the value stream of the service.

c) Identify the service flow.

d) Supply on demand

e) Seek perfection.

According to the principle "a”, the value of a service or product defined by the user customer, which must meet their needs with the specific price, for this, it is necessary to understand what the customer really wants. In order to understand the value identified by customer eyes, companies must go through difficult and comprehensive reorganizations of people and business processes (Abdi et al., 2006).

The "b" principle focuses on seeking to understand all the activities needed to provide a specific service and then optimize the entire process from the end customer's point of view. The customer point of view is extremely important because it helps to identify activities that clearly add value, activities that do not add value but cannot be avoided, and activities that do not add value and can be avoided. After the value has been specified and the value streams have been identified, the next step, “c”, is to identify the activities that add value to the flow without interruption. Lovelock and Wright (2001) propose that the process-mapping tool can be used to identify value-adding activity.

Principle "d" seeks to respond to customer demand, meaning that companies must design their operations to meet the ever-changing requirements of end customers. Thus, service organization always finds a paradox related to flexibility versus efficiency. For Senge (1990) people operate under many different mental models. So trying to predict the behaviors of others are a waste, since it is a lengthy and often inaccurate process and therefore should be eliminated. However, the use of lean tools and concepts, especially applying value stream mapping and derivation techniques, reduces ambiguity and rework in interpersonal relationships (Abdi et al., 2006; Akdağ et al., 2017; Thomas, 2018; Cavdur et al., 2019).

Finally, the "e" principle focuses on the pursuit of perfection, with the complete elimination of waste, and it is at this point that every activity creates value for the customer. If a company can do, the first four steps well, all activities become transparent. This allows people to easily identify and eliminate waste and focus on improving value-creating activities. The first four steps interact in a "virtuous circle" that enables the pursuit of perfection (Abdi et al., 2006). 
INDEPENDENT JOURNAL OF MANAGEMENT \& PRODUCTION (IJM\&P)

http://www.ijmp.jor.br

v. 12, n. 4, May-June 2021

ISSN: 2236-269X

DOI: 10.14807/ijmp.v12i4.1332

Systematic elimination of waste will reduce the company's operating costs by meeting the customer's desire for maximum value at the lowest price. Although perfection is never achieved, your pursuit is a goal worth striving for, as it helps to keep a constant watch on practices that may contain some kind of waste. The specific context of service and the pursuit of perfection is related to people and their behaviors, meaning it takes advantage of the transparency brought about by the first four steps in order to more easily identify and eliminate non-value-creating behaviors (Abdi et al., 2006; Ferreira et al., 2018; Balocco et al., 2019).

Abdi et al. (2006) identified lean characteristics, applied to service processes in companies that sought to implement lean as an approach to quickly take control of key customer service processes by applying improvements and sustainable advances in its processes and ultimately to deliver tangible benefits not only for customers but also measurable cost-effectiveness for the organization.

Often the application of lean principles is still confusing itself with cost reduction, but one of the focal points of lean principles is value creation. According to Womack and Jones (1996), as lean spread beyond the shop floor, its previously focus on cost reduction has shifted to an approach focused on constantly increasing consumer value through the addition of some product and service-specific characteristics and waste removal. For Hines et al. (2004), the value is created if:

- The internal waste is reduced, eliminating costly activities and reducing associated costs, which ultimately increases customer value proposition,

- The Features or services, which are valued by customers, are additionally offered.

Finally, in the last learning stage presented by McGill and Slocum (1993), organizations seek to maximize the learning opportunities of their employees, suppliers, customers, and even competitors. At this stage, each change is seen as an opportunity for the organization to learn with a focus on capturing customer needs (Hines et al., 2002; Ferreira et al., 2018).

Although lean thinking is largely related to the strategic and competitive advantages gained by organizations seeking to apply its principles, however, throughout the evolution of its concepts. It is evident that many of the Criticisms of lean relate to the introduction of its concepts in different sectors in which its principles originated (the shop floor), and some key aspects can be highlighted, such as the inability to deal with the variability of situations and the lack of understanding of human aspects (Hines et al., 2004). 
DOI: 10.14807/ijmp.v12i4.1332

\subsection{Value Stream Mapping}

Womack and Jones (1996) present the concept of value as one of lean's principles, for them value is created by providing customer resources at the right time at an appropriate price, respecting the individuality of each customer. Therefore, the value can be considered as a critical point for lean onset and can only be set by the end customer (user). For Hines et al. (1998), lean thinking can be defined as a management philosophy that adds perceived customer value by adding features to products and services and removing non-value adding activities.

Based on this thinking, many tools have emerged in order to avoid possible waste; such tools have been employed, especially on the shop floor and in processes related to product development. However, these same tools were mostly limited to making processes better and faster without first understanding what really should be done. As a result, by employing such tools companies may only be doing the "wrong" activity more efficiently (Maleyeff, 2006; Braglia et al., 2006).

In this context comes an alternative tool aligned with lean culture that in fact seeks to identify the main waste of a process. Value Stream Management (VSM). This tool, which also originated on the shop floor, seeks to redefine and redesign production systems that lead to waste reduction. The VSM consists of the creation of two value maps: the first one representing the current state of materials and information flow and the second representing the same state or future state flows (Singh et al., 2010; Braglia et al., 2009; Emiliani \& Stec, 2004; Lasa et al., 2008; Thomas, 2018; Cavdur et al., 2019).

Shou et al. (2017) sought to better understanding the use of VSM in five different sectors: manufacturing, health, construction, product development and services. For this, they conducted a systematic literature review on the use of VSM analyzing four (4) main elements:

- $\quad$ The metrics for each current state.

- Techniques for future state optimization.

- The benefits achieved by implementing VSM.

- Critical factors for the successful use of VSM in each industry.

When searching for the term Value Stream Map (VSM) in the Web of Science database, 227 results were found. As shown in Figure 2, it is possible to verify a growth pattern in the number of publications similar to that presented by Shou et al. (2017). However, by adding the term Service to the search, the number of results in the period reached only 17. 
DOI: 10.14807/ijmp.v12i4.1332

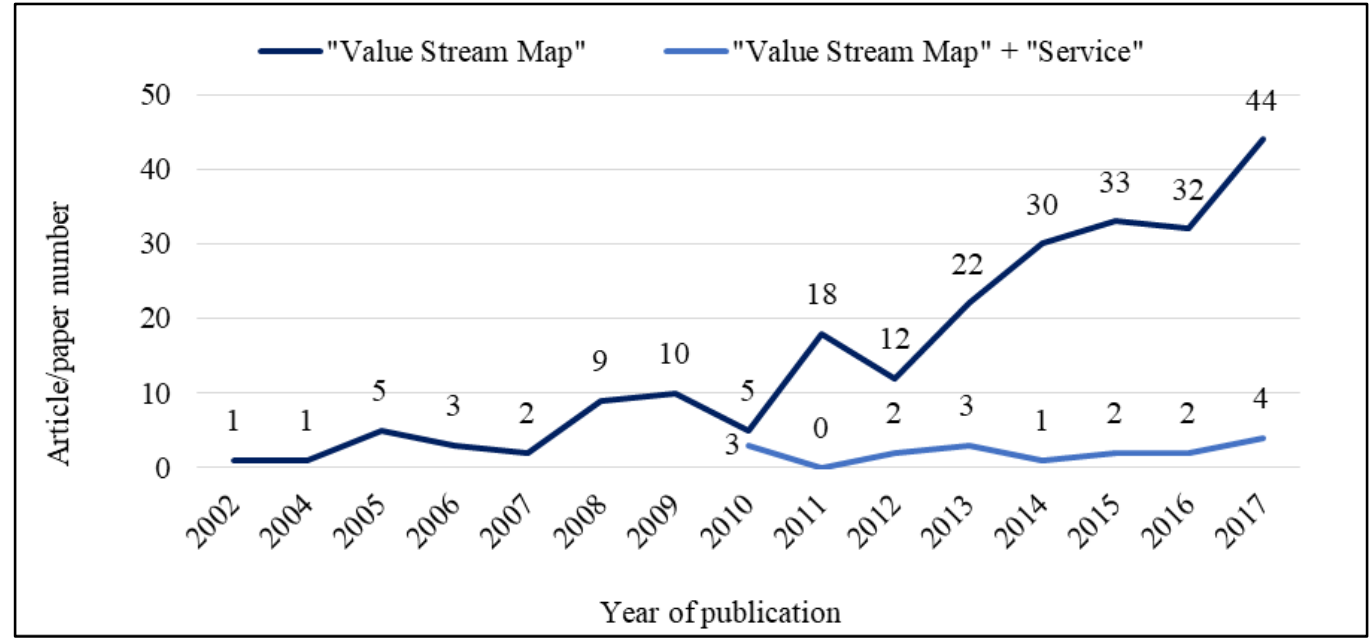

Figure 2: Evolution in the number of publications (Web of Science) Source: Web of Science, 2018

It is evident that VSM application is still incipient in the service sector, as shown in Table 1 . The publications pertaining to this sector correspond to only $2 \%$ of the articles elected by Shou et al. (2017).

Table 1: Distribution of publications by sector

\begin{tabular}{lcccccc}
\hline & \multicolumn{7}{c}{ Period (Years) } \\
\cline { 2 - 7 } \multicolumn{1}{c}{ Sector } & $\mathbf{1 9 9 9 - 2 0 0 3}$ & $\mathbf{2 0 0 4 - 2 0 0 8}$ & $\mathbf{2 0 0 9 - 2 0 1 3}$ & $\mathbf{2 0 1 4 - 2 0 1 6}$ & Subtotal & Percentage (\%) \\
\hline Manufacturing & 2 & 11 & 37 & 41 & 91 & 69 \\
Health & 0 & 3 & 9 & 7 & 19 & 15 \\
Building & 1 & 0 & 4 & 5 & 10 & 8 \\
Production & 0 & 1 & 1 & 6 & 8 & 6 \\
Services & 0 & 1 & 2 & 0 & 3 & 2 \\
\hline \multicolumn{1}{c}{ Total } & $\mathbf{3}$ & $\mathbf{1 6}$ & $\mathbf{5 3}$ & $\mathbf{5 9}$ & $\mathbf{1 3 1}$ & $\mathbf{1 0 0}$ \\
\hline \multicolumn{7}{c}{ Source: SHOU et al. (2017) }
\end{tabular}

Despite the few publications on the application of VSM in services, Emiliani and Stec (2004) argue that value stream mapping can be used to map any kind of business process, including business-to-business sales, retail sales, e-commerce, health, education and government services; always aiming to eliminate waste and add value to activities that consumers want and are willing to pay. Thus, it is evident that the use of lean concepts started to be applied beyond the factory floor, also seeking to solve the quality vs costs in the service sector (Thomas, 2018; Gębczyńska, 2016; Cavdur et al., 2019).

This gives rise to a new approach to Value Stream Map (VSM), Service Value Stream Management (SVSM), keeping the same focus on waste reduction as its predecessor, yet with its own specifics (Hines et al., 2004; Bonaccorsi et al., 2011; Emiliani \& Stec, 2004; Thomas, 2018; Cavdur et al., 2019). 
DOI: 10.14807/ijmp.v12i4.1332

Successful use of SVSM has being related to the commitment to lean culture and lean learning throughout the organization, as its implementation requires top management to be committed to using the methodology, and the entire team must be properly trained and key people should deepen into lean culture, becoming a reference for others (Bonaccorsi et al., 2011).

Abdi et al. (2006) presented the identification of the service value stream as one of the five principles in the lean approach from the service perspective. This principle focuses on seeking to understand all the activities required to provide a specific service and then optimize the process from the end customer's point of view.

The customer point of view is extremely important because it helps to identify activities that clearly add value, activities that do not add value but cannot be avoided, and activities that do not add value and can be avoided. Bonaccorsi et al. (2011), reinforce that the identification of value streams should be made considering those services that have the highest order recurrence or the highest revenue for the company. Identify which are and where the waste are and the data collection from customers is the answer.

Paciarotti et al. (2011) point out that there are no significant data on the application of SVSM. Nevertheless, in their case study, Ray and John (2011) achieve a 75\% reduction in the cycle time of the study operation using VSM. The analysis of the problem started with process mapping and after the brainstorming with the team members, the result of the discussion led to the use of the value stream map along with a cause-effect analysis to identify the root cause of the waste and then come to the identification of the solutions.

Barber and Tietje (2013) show that within the service sector activities are directly influenced by relationships, decisions, negotiations and conflicts. Thus, the value is the result of intangible relationships and its application of VSM in this sector lies in the elimination of errors, inappropriate procedures and developing customer satisfaction, so that current state measures are related to process performance and resources involved. For them, the entire sales process involves the co-creation of value between sellers and customers. In this context, the sales process measures are divided into two groups:

- Time available for customer engagement.

- Data entry in tracking systems. 
DOI: 10.14807/ijmp.v12i4.1332

Despite the investment of resources, time and effort on both sides, many activities in this process do not add value. Finally, they suggest a cross-sectional study in the service industry comparing the sales process before and after the application of any lean initiative, listing three challenges for using VSM in the sales industry:

- Understand deeply the activities of seller and buyer figures.

- Need to establish value metrics in the customer-focused relationship.

- Need to do new studies to test alternative value streams for the sales process.

In view of these previous studies, the interest in observing the use of lean concepts emerged, in order to validate the possibility of applying these concepts in a sales department, identifying possible sources of waste.

\section{METHODOLOGY}

The research was carried out through personal interviews, in loco, with managers and analysts that work in this airline company. Data were gathered semi-structured interviews. Interviews were conducted face-to-face. The duration of the interviews ranged from 40 to 55 minutes and 25 professionals were interviewed in 2019.

To better understand how company engage customers in their business practices, a qualitative exploratory case study was carried out. A case study is a tool to generate and test a theory that is aligned with a current proposal. The case study allows the comprehension of the research field, and it is appropriate for exploratory research. The research was developed in two steps: gathering data (current situation of the company before the implementation of the SVSM) and data analysis (with implementation of the SVSM system).

After identifying the main source of revenue for the area company, object of this study, the initial analysis of the problem was made through a brainstorm with the team members, in this case the salespeople, focusing on the possible causes for the loss of leadership this company to its competitors. Data were collected through interviews with the sales department who has information on the airline's nineteen major consumer customers, which in total account for 35\% of B2B annual sales revenue.

From then one we choose to use a cause and effect diagram, as it consists of a graphical form used as an analysis methodology to represent influence factors (causes) on a given problem (effect). 
DOI: 10.14807/ijmp.v12i4.1332

Thus, the first phase of this work was structured in order to identify the causes within the internal processes of the sales department, for the loss of market leadership through the cause and effect analysis structured in four steps:

- Step 1: Identify the largest source of revenue/relevance to the company.

- Step 2: Conduct Brainstorming with salespeople who hold customer information.

- Step 3: Draw the cause and effect diagram, based on the information gathered, from the salespeople.

- Step 4: Identify causes that led to loss of market leadership within the sales department processes with the highest incidence of waste.

\section{VALUE STREMA MAP}

From this point on they were identified which are and where are the highest incidences of waste. This identification occurred through customer data collection and at the end of this process, the collected data should:

- Clarify customer needs.

- Check the defect correction category by giving weight to each one.

- Establish which of these is most critical to the company.

The next step was to draw the value stream using previously defined icons, always considering the customer icon as the main element. After defining icons, relevant information was collected for each step of the process designed to be classified as, add value, necessary or waste. From this point on, improvement goals were then defined for each activity and finally the map was redrawn to form the future map in order to eliminate the identified waste (Bonaccorsi et al., 2011; Braglia et al., 2006; Bauer et al., 2019).

Therefore, the second part of the work was to map the value stream of the processes previously raised by the cause and effect analysis. The focus was on identifying the activities that add and those that do not add value:

- Step 5: Conduct interviews with salespeople and customers to draw value streams.

- Step 6: Draw the present map (current state).

- Step 7: Identify and classify activities (add value, not add and needed).

- $\quad$ Step 8: Draw the future map (desired state). 
INDEPENDENT JOURNAL OF MANAGEMENT \& PRODUCTION (IJM\&P)

http://www.ijmp.jor.br

v. 12, n. 4, May-June 2021

ISSN: 2236-269X

DOI: $10.14807 /$ ijmp.v12i4.1332

- Step 9: Present the board with corrections.

In summary, the work is structured in two distinct phases, composed in nine stages, the first four occurring in the process identification phase and the other five occurring in the activities identification phase and being improved, as shown in Table 2.

Table 2: Phases and steps adopted in the methodology

\begin{tabular}{|c|c|c|}
\hline Phase & Stage & Description \\
\hline \multirow{4}{*}{ Cause Identification } & 1 & Identify the largest source of revenue/relevance to the company. \\
\hline & 2 & Brainstorming salespeople who hold customer information \\
\hline & 3 & Draw the cause and effect diagram based on the information collected. \\
\hline & 4 & $\begin{array}{l}\text { Identify causes within sales department processes with the highest } \\
\text { incidence of waste. }\end{array}$ \\
\hline \multirow{5}{*}{$\begin{array}{l}\text { Identification of } \\
\text { activities to be } \\
\text { improved }\end{array}$} & 5 & $\begin{array}{l}\text { Conduct interviews with sellers and consumer customers to draw value } \\
\text { streams }\end{array}$ \\
\hline & 6 & Draw the present map (current state) \\
\hline & 7 & Identify and classify activities (add value, do not add and needed) \\
\hline & 8 & Draw the future map (desired state) \\
\hline & 9 & Display the board with corrections \\
\hline
\end{tabular}

From the identification of the main processes in the sales area, two value maps were drawn, the present map and the future map, considering the data obtained from the case study and interviews. The value maps were designed as presented by Barber and Tietje (2013), the top of the map describes the activities that are pertinent to the sellers as well as the time spent in each of them, while the bottom of the map will describe the activities and the customers' time spent.

Results were divided into two groups, quantitative data and qualitative data. Quantitative data are the expected results of a sales force, which according to Zoltners et al. (2008) are characterized by the number of sales, volume of revenue realized and market share, market share achieved in a given period of time. In the case of this research, the market share indicator was adopted because it is a public data, available on the Internet. Qualitative data, on the other hand, are complementary to quantitative data within a research, because they are meanings, motivations and values.

These data were obtained through interviews with consumer customers about their experience with the service provided. Later, in the second moment, the future map was designed based on the expected value stream after the organizational restructuring, with the elimination of waste from the process previously selected by the cause and effect analysis.

The same results, both quantitative and qualitative, considered at the first moment were also raised within an equivalent period after restructuring. Finally, a table was presented based 
INDEPENDENT JOURNAL OF MANAGEMENT \& PRODUCTION (IJM\&P)

http://www.ijmp.jor.br

v. 12, n. 4, May-June 2021

ISSN: 2236-269X

DOI: 10.14807/ijmp.v12i4.1332

on the eight types of waste presented by Keyte and Locher (2004), as described in Table 3, and the identified needs of customers.

Table 3: Potential Sources of Waste in the Sales Process

\begin{tabular}{|c|c|}
\hline Waste & Example applied to sales \\
\hline Overproduction & Generate solutions before the customer is ready to buy \\
\hline Inventory & $\begin{array}{c}\text { Excess supplies of printed brochures } \\
\end{array}$ \\
\hline Waiting time & $\begin{array}{c}\text { Awaiting approval from others in the sales or customer organization, } \\
\text { and awaiting customer input }\end{array}$ \\
\hline Processing & Lost, Unnecessary, or Excessive Information Requests \\
\hline Corrections & $\begin{array}{c}\text { Errors in data, design, invoice and proposal } \\
\end{array}$ \\
\hline Handling & $\begin{array}{c}\text { Walk to/from the copier, central archive, fax, other offices or fly and } \\
\text { drive to meetings and appointments }\end{array}$ \\
\hline Document Distribution & Distribution of documents for review and approval \\
\hline Authority & $\begin{array}{l}\text { Limited authority and responsibility, inadequate management } \\
\text { command and control. Technological tools available. }\end{array}$ \\
\hline
\end{tabular}

\section{RESULT}

This work was carried out within a Brazilian airline, which, due to changes in the competitive scenario of the Brazilian air market, lost market leadership and sought new ways to reposition itself against its competitors. It is in this scenario that the company promoted a series of changes, especially promoting organizational restructurings, which created opportunities for the present study. Thus, this research sought to evaluate, through a case study and using the tools of cause and effect analysis and value stream mapping, how the activities performed by the sales department could generate customer value seeking the resumption of market leadership.

In the company's structure, the sales department is divided into two, the direct sales department focused on the end consumer and in which the customer buys his ticket directly through the airline's website and indirect sales, that is, when there is a need for the sale occur through an intermediary.

Indirect sales can still be destined for two distinct customer groups depending on the type of travel the passenger takes. There are groups of leisure and business travelers. In this paper, the focus was on those traveling on business, as they individually contributed higher revenues to the company.

For this form of selling to exist within the company, one must understand that there is a peculiarity in the way the company relates to its customers. Precisely because the sale does not occur directly to the passenger, there is the formation of a tripod where each actor is necessary for the sale to occur and the actors involved are: 
DOI: 10.14807/ijmp.v12i4.1332

- Airlines: Offer the air transportation service.

- Intermediaries: Responsible for operationalizing the sale to the customer.

- Client Companies: These are companies that require their employees to travel for business continuity.

Thus, arise a B2B relationship where the airline sells tickets to other companies and these companies themselves are the B2B customers of this relationship. Within the client companies, two distinct types of clients involved in this tripod can still be characterized: the client clients, who are the employees of the business travelers who are the passengers themselves and the client clients who are the company employees responsible for hiring. Intermediaries and intermediation with airlines.

A total of 41 activities has been identified within the seven sets. According to Table 4 it is possible to identify that twelve activities (29\%) were performed by the customer, eighteen activities (44\%) by the salesmen, while the intermediaries were responsible for eleven activities (27\%), only one less activity compared to the one client.

Table 4: Distribution of map activities present by process agents (number)

\begin{tabular}{ccccccccc}
\hline Agent/Activity & A & B & C & D & E & F & G & Total \\
\hline \hline Client & 1 & 1 & 2 & & 2 & 4 & 2 & 12 \\
Intermediate & 2 & 2 & 2 & 1 & 2 & 1 & 1 & 11 \\
Salesman & 2 & 2 & 3 & 1 & 3 & 4 & 3 & 18 \\
\hline Total & $\mathbf{5}$ & $\mathbf{5}$ & $\mathbf{7}$ & $\mathbf{2}$ & $\mathbf{7}$ & $\mathbf{9}$ & $\mathbf{6}$ & $\mathbf{4 1}$ \\
\hline \hline
\end{tabular}

When it comes to the time required to carry out the activities, the distribution becomes more balanced: 37\% for the customer, 30\% for intermediaries and 33\% for sellers. As it can be seen in Table 5, the total time required from the first contact to the return to the customer is 26.3 days, with activity sets C (preparation), F (operationalization) and B (evaluation) being those that demand the most time respectively, together accounting for $96 \%$ of the total time.

Table 5: Distribution of present map times by process agents (days)

\begin{tabular}{ccccccccc}
\hline Agent/Activity & A & B & C & D & E & F & G & Total \\
\hline \hline Client & 0,01 & 0,01 & 4,69 & & 0,04 & 5,06 & 0,02 & 9,83 \\
Intermediate & 0,03 & 2,03 & 4,69 & 0,01 & 0,10 & 1,00 & 0,02 & 7,88 \\
Salesman & 0,02 & 1,04 & 5,70 & 0,01 & 0,72 & 1,04 & 0,06 & 8,60 \\
\hline Total & $\mathbf{0 , 1}$ & $\mathbf{3 , 1}$ & $\mathbf{1 5 , 1}$ & $\mathbf{0 , 0}$ & $\mathbf{0 , 9}$ & $\mathbf{7 , 1}$ & $\mathbf{0 , 1}$ & $\mathbf{2 6 , 3}$ \\
\hline \hline
\end{tabular}

Source: Field Research

After interviews with clients, it was possible to obtain qualitative information to classify the activities as "Add value”, "Do not add value, but necessary” and "Do not add value.” As shown in Table 6 , only $15 \%$ of the activities actually add value and $54 \%$, while not adding 
DOI: $10.14807 /$ ijmp.v12i4.1332

value, were needed. Activity set D (alignment) was the only one that presented only non-value added activities, and as presented earlier, this is the only set that does not involve customer participation.

Table 6: Distribution of map activities present by activity type (number)

\begin{tabular}{ccccccccc}
\hline Type/Activity & A & B & C & D & E & F & G & Total \\
\hline \hline Aggregate & & & & & 3 & 2 & 1 & 6 \\
Not aggregate & 2 & 2 & 2 & 2 & 2 & 3 & & 13 \\
Required & 3 & 3 & 5 & & 2 & 4 & 5 & 22 \\
\hline Total & $\mathbf{5}$ & $\mathbf{5}$ & $\mathbf{7}$ & $\mathbf{2}$ & $\mathbf{7}$ & $\mathbf{9}$ & $\mathbf{6}$ & $\mathbf{4 1}$ \\
\hline \hline
\end{tabular}

Source: Field Research

By observing the times required to perform each activity, presented in Table 7, those that 'add value' corresponded to only $4 \%$ of the total time shown on the map, and the activities classified in this flow as 'Required' reached 71\%. Although needed, these activities could still be reviewed, while the other $25 \%$ of the time is devoted to "non-value-added" activities and could be eliminated to reduce the total map time.

Table 7: Distribution of present map times by activity type (days)

\begin{tabular}{ccccccccc}
\hline Type/Activity & A & $\mathbf{B}$ & $\mathbf{C}$ & $\mathbf{D}$ & $\mathbf{E}$ & $\mathbf{F}$ & $\mathbf{G}$ & Total \\
\hline \hline Aggregate & & & & & 0,1 & 1,0 & 0,0 & 1,1 \\
Not Aggregate & 0,0 & 1,0 & 4,7 & 0,0 & 0,7 & 0,1 & & 6,5 \\
Required & 0,0 & 2,0 & 10,4 & & 0,1 & 6,0 & 0,1 & 18,7 \\
\hline Total & $\mathbf{0 , 1}$ & $\mathbf{3 , 1}$ & $\mathbf{1 5 , 1}$ & $\mathbf{0 , 0}$ & $\mathbf{0 , 9}$ & $\mathbf{7 , 1}$ & $\mathbf{0 , 1}$ & $\mathbf{2 6 , 3}$ \\
\hline \hline
\end{tabular}

Qualitative information collected from customers to qualify the activities of the present map was also used to identify potential sources of waste throughout the flow, which go beyond reducing time by eliminating non-value added activities. Potential wastes were classified according to that proposed by Keyte and Locher (2004).

By using the present value flow map it was possible to identify what are the existing waste that in the customer's view are in the activities related to the root cause "Relationship Process”. Subsequently, with the future map design, the possible corrections for the indicated wastes were presented; the results are presented in Table 8. This table has the description of the main wastes, the ideal model for resolution and the possible corrective actions, leading to take into account the customer's vision for each type of waste identified within the sales area. 
DOI: 10.14807/ijmp.v12i4.1332

Table 8: Summary table: customer optics and corrective actions.

\begin{tabular}{|c|}
\hline Type \\
\hline
\end{tabular}

A new negotiation model adopted by the airline, different from the one practiced in the market, led to customer discontent for not making clear in the contract what the negotiated

The consumer customer wants clear contract terms, as he needs to justify his decisions to his superiors.
Flex the contract negotiation model to meet the needs of each client. conditions were.

During the meetings,
printed material was
presented with new
destinations and product
changes, which were often
discarded by the client.

The customer's waiting time from the first contact until

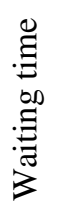
the contract was made was the subject of constant complaints, especially at the time of contract renewal that followed the same flow of a new agreement.

The same information is
requested and sent by the
different actors of the
r

Error in the registration and sellers. information sent by the intermediaries makes it impossible for the airline to maintain the conditions agreed between customers

information sent by the
intermediaries makes it
impossible for the airline to
maintain the conditions
agreed between customers
and sellers.

\begin{abstract}
The consumer customer wants to
be up to date with information

they deem relevant. The material presented should contain quantitative information, such as service expenses and the purchasing profile of the user customers.
\end{abstract}

The customer wants a clear answer, with reliable deadlines and that their requests are met quickly.
Submit material with quantitative and not only qualitative information.
The time spent traveling from the seller to the customer to hold the meeting.
The client wants a more frequent contact focused on the presentation of results and not just the search to sign the contract.
Adopt a process of automatic extension of contracts, taking advantage of the time of meetings to update the contract.
Sellers and intermediaries should be able to communicate to exchange the information they need without having to be contacted numerous times to obtain the same information.
Create a flow for to reach the airline. customer information
For the client the conditions available in the intermediary's system on the first day after the commencement of the contract. negotiated with the airline must be
Adoption of CRM tool, which facilitates the building/updating of customer information.
Customer segmentation with a visit routine adapted to the needs of each one, including videoconferencing for clients who do not have the profile for face-to-face visits.

Adoption of electronic signature to facilitate physical contracts implies in cases of loss and loss of Sending documents digitally. documentation. the process of formalization of the contract. 
INDEPENDENT JOURNAL OF MANAGEMENT \& PRODUCTION (IJM\&P)

http://www.ijmp.jor.br

v. 12, n. 4, May-June 2021

ISSN: 2236-269X

DOI: 10.14807/ijmp.v12i4.1332

\begin{tabular}{cccc}
\hline Type & Description & $\begin{array}{c}\text { Ideal model from the customer's } \\
\text { perspective }\end{array}$ & Corrective action \\
\hline & $\begin{array}{c}\text { The seller needed broker } \\
\text { approval to contact the } \\
\text { customer. }\end{array}$ & $\begin{array}{c}\text { Quick and easy contact with } \\
\text { someone who has the right answer } \\
\text { to your questions and } \\
\text { troubleshooting. }\end{array}$ & $\begin{array}{c}\text { For the resolution of } \\
\text { operational themes, the } \\
\text { option would be to } \\
\text { create a dedicated } \\
\text { customer service cell } \\
\text { user. }\end{array}$ \\
\hline
\end{tabular}

Source: Developed by the authors

Following the design of the maps and the introduction of some of the corrective actions presented future map, the quantitative result achieved by the airline after the restructuring period of the B2B sales department was determined. The quantitative data used for the valuation were the publicly available market share data.

Processes were mapped and performance indicators defined. After analyzing the current situation of the airline's sales department, the Service Value Stream Management (SVSM) technique was applied, which brought significant improvements in the company's sales operations and a considerable reduction in operational process time and consequently reduction in the company's operating costs, as shown in Figures 3 and 4. There was a more than $62 \%$ reduction in sales process time, allowing significant operating gain for the airline company.

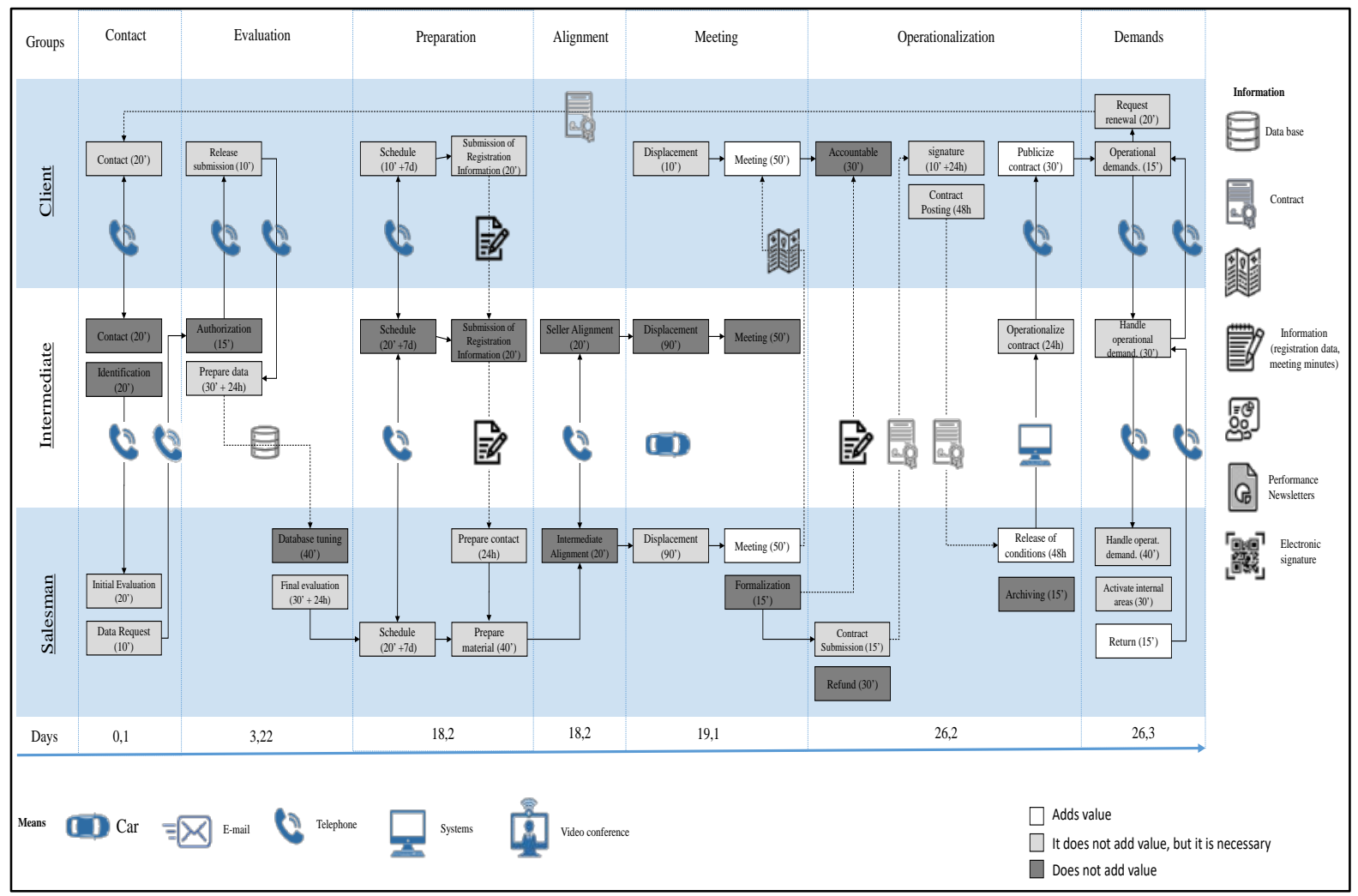

Figure 3: Sales Process Flow Mapping (No Improvements) 
DOI: 10.14807/ijmp.v12i4.1332

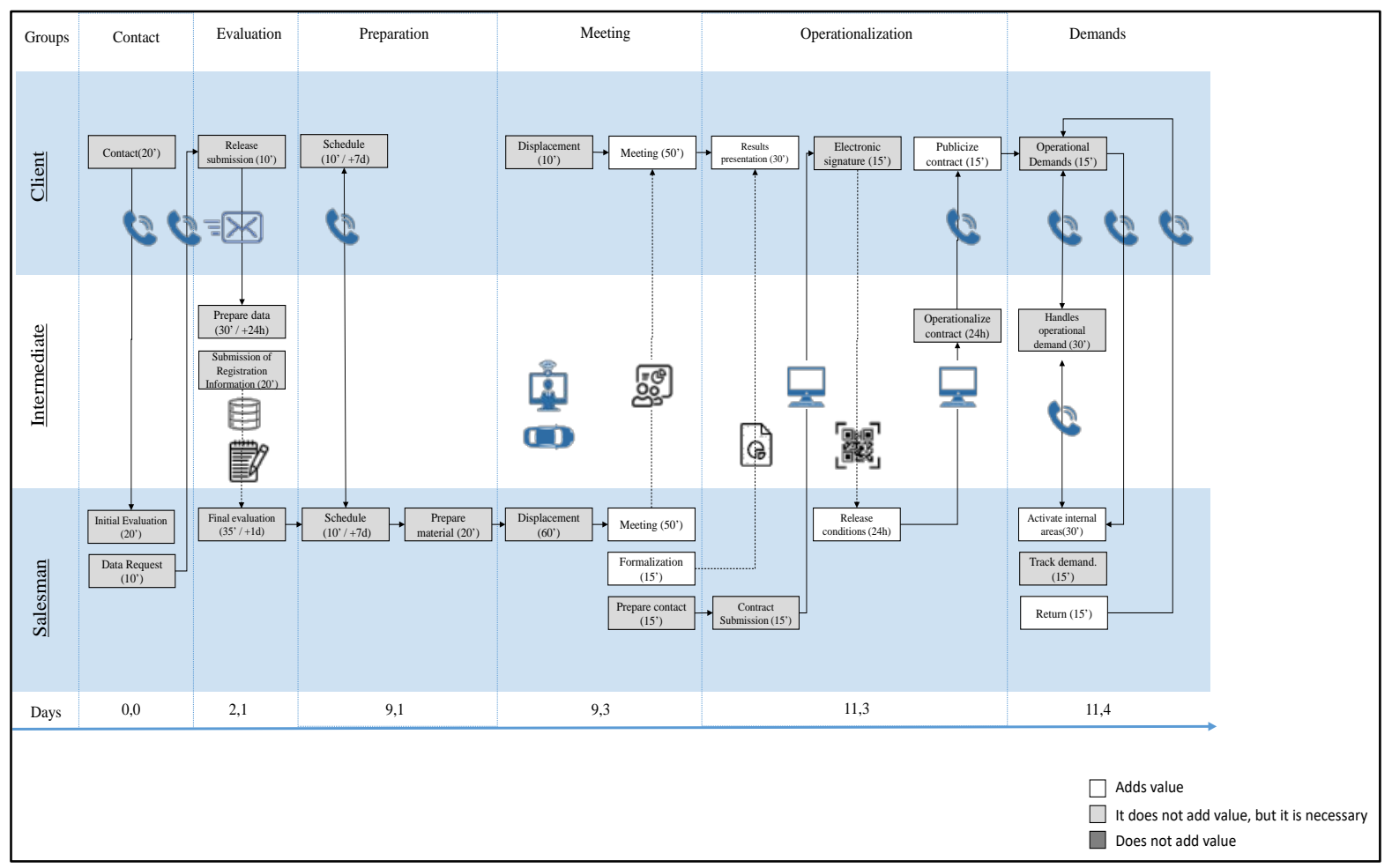

Figure 4: Service Value Stream Management (SVSM) - Improvements

\section{CONCLUSION}

In this paper, a case study was conducted in a Brazilian airline that recently reduced its staff and adopted new organizational structures. In this context, the sales team dedicated to $\mathrm{B} 2 \mathrm{~B}$, a highly revenue-relevant business line for the company, also underwent a restructuring process. During this period of organizational review, the company, which was the market leader in its segment, lost this position to its main competitor.

The data collection of this research occurred through interviews with airline sales department because they are the holders of the closest relationship with consumer customers and present themselves as the channel of requests and complaints to the company.

The purpose of the interviews with sellers was to better understand the main sources of waste pointed out by customers, which could indicate the possible causes for the loss of market leadership. Therefore, data were collected directly from customers, in order to propose corrective actions for the current model, to define a set of indicators that seek to direct a model of the relationship between company and customer that meets the expectations of both and, above all, generates customer value.

From the case study and data collection, it has been applied root cause analysis in order to identify what the possible causes led the company to lose market leadership. Thus, it was identified which processes of the sales area, from the perspective of the consumer customer, 
DOI: 10.14807/ijmp.v12i4.1332

do not add value in the B2B relationship. Subsequently, the principles of the value stream map were used to map waste and propose ways to eliminate it in order to generate customer value.

Through root cause analysis, it was possible to identify that the relationship process is one of the main decision factors for consumer customers in a B2B business relationship. Although the value stream map tool is still little explored in services, using it to map sales department activities involved in customer-seller relationships can yield consistent benefits in an organizational restructuring process.

In the case study, it is evident that it is possible to identify waste and act on it, prioritizing activities that add value to the customer. Regarding the relationship with the customer, it is also evident that the benefits found with the application of the tool are related to:

a) Creating a direct relationship between the customer and seller by eliminating intermediaries making the whole communication process more efficient, eliminating non-value adding activities and transforming necessary activities into value adding activities.

b) Exchange of relevant information on the use of the services provided. In the decentralized structure, the material sent to the customer was summarized in the formalization of the business relationship between the parties. With restructuring a whole tooling was developed to provide the customer with relevant information about the use of the services provided.

c) Quick resolution of demands sent by customers to their suppliers (sellers and intermediaries).

Using the methodology was possible to identify cross-sectional causes in the customer's view of the company's loss of leadership in the B2B market. This also implies that it is possible to use lean principles in a sales area of a service company. This makes it possible to expand the application of these concepts beyond the shop floor.

Recommendations for future studies, in order to support the application of the method in services: It is suggested to replicate the methodology in:

I) Other service providers, but operating in different air transport segments.

II) Other areas of the company, other than the sales department. 
DOI: $10.14807 /$ ijmp.v12i4.1332

Corrective actions were proposed based on the identified wastes, always focusing on the client's vision of an ideal relationship model. At this point, adding the salesperson's vision to the ideal relationship model may be a next step to validate the application of the method.

\section{REFERENCES}

Abdi, F., Shavarini, S. K., \& Hoseini, S. M. S. (2006). Glean Lean: How to use Lean Approach in Service Industries? Journal of Services Research, 6, 191-206, Special Issue.

Akdağ, H. C., Çalişkan, E., \& Toma, S. (2017).. Lean process design for a radiology department. Business Process Management Journal, 23(4), 779-791.

Balocco, R., Cavallo, A., Ghezzi, A., \& Mirabent, J. B. (2019). Lean business models change process in digital entrepreneurship. Business Process Management Journal, 25(7), 15201542.

Barber, C. S., \& Tietje, B. C. (2013). A Research Agenda for Value Stream Mapping the Sales Process. Journal of Personal Selling \& Sales Management, 28(2), 155-165.

Bauer, J. M., Vargas, A., Sellito, M. A., Souza, M. C., \& Vaccaro, G. L. (2019). The thinking process of the theory of constraints applied to public healthcare. Business Process Management Journal, 25(7), 1543-1563.

Bonaccorsi, A., Carmignani, G., \& Zammori, F. (2011). Service Value Stream Management (SVSM).: Developing Lean Thinking in the Service Industry. Journal of Service Science and Management, 4(4), 428-439.

Bose, R. (2002). Customer Relationship Management: Key Components for IT Success, Industrial. Management \& Data Systems, 102(2), 89-97.

Braglia, M., Carmignani, G., \& Zammori, F. (2006). A New Value Stream Mapping Approach for Complex Production Systems. International Journal of Production Research, 44(18-19), 3929-3952.

Braglia, M., Frosolini, M., \& Zammori, F. (2009). Uncertainty in Value Stream Mapping Analysis. International Journal of Logistic: Research and Application, 12(6), 435-453.

Caceres, R. C., \& Paparoidamis, N. G. (2007). Service Quality, Relationship Satisfaction, Trust, Commitment and Business-to-Business Loyalty. European Journal of Marketing, 41(7/8), 836-867.

Cavdur. F., Yagmahan, B., Oguscan, E., Arslan, N., \& Sahan, N. (2019). Lean service system design: a simulation-based VSM case study. Business Process Management Journal, 25(7), 1802-1821.

Cronin, J. J., \& Taylor, S. A. (1992). Measuring Service Quality: A Reexamination and Extension. Journal of Marketing, 56(3), 55-68.

Emiliani, M. L., \& Stec, D. J. (2004). Using Value-Stream Maps to Improve Leadership. Leadership \& Organization Development Journal, 25(8), 622-645.

Ferreira, G. S. A., Silva, U. R., Costa, A. L., Pádua, S. I. D., (2018). The promotion of BPM and lean in the health sector: main results. Business Process Management Journal, 24(2), 400-424.

Gębczyńska, A. (2016). Strategy implementation efficiency on the process level. Business Process Management Journal, 22(6), 1079-1098. 
DOI: $10.14807 /$ ijmp.v12i4.1332

Gibbert, M., Leibold, M., \& Probst, G. (2002). Five Styles of Customer Knowledge Management and How Smart Companies use then to Create Value. European Management Journal, 20(5), 459-469.

Gummesson, E., \& Polese, F. (2009). B2B is Not an Island! Journal of Business \& Industrial Marketing, 24(5/6), 337-350.

Håkansson, H., Ford, D., Gadde, L. E., Snehota, I., \& Waluszewski, A. (2009). Business in Networks, John Wiley \& Sons, Chichester.

Hines, P., Holweg, M., \& Rich, N. (2004). Learning to Evolve: A Review of Contemporary Lean Thinking. International Journal of Operations \& Production Management, 24), 994-1011.

Hines, P., Rich, N., Bicheno, J., Brunt, D., Taylor, D., Butterworth, C., \& Sullivan, J. (1998). Value Stream Management. The International Journal of Logistic Management, 9(1), 2542.

Hines, P., Silvi, R., \& Bartolini, M. (2002). Demand Chain Management: An Integrative Approach in Automotive Retailing. Journal of Operations Management, 20(3), 707-28.

Kaplan, S., \& Sawhney, M. (2000). E-Hubs: The New B2B Marketplaces. Harvard Business Review, 78(3, p. 97-103.

Keyte, B., \& Locher, D. (2004). The Complete Lean Enterprise: Value Stream Mapping for Administrative and Office Processes, New York: Productivity Press.

Khodakarami, F., \& Chan, Y. E. (2014). Exploring the Role of Customer Relationship Management (CRM). Systems in Customer Knowledge Creation. Information \& Management, 51(1), 27-42.

Khosravi, A. (2016). Business process rearrangement and renaming: A new approach to process orientation and improvement. Business Process Management Journal, 22(1), 116139.

Lasa, I. S., Laburu, C. O., \& Castro Vila, R. (2008).. An Evaluation of the Value StreamMapping Tool. Business Process Management Journal, 14(1), 39-52.

Lee, R. P., Naylor, G., \& Chen, Q. (2011). Linking Customer Resources to Firm Success: The Role of Marketing Program Implementation. Journal of Business Research, 64(4), 394400.

Leonidou, L. (2004). Industrial Manufacturer-Customer Relationships: The Discriminant Role of the Buying Situation. Industrial Marketing Management, 33, 731-742.

Li, T., \& Calantone, R. J. (1998). The Impact of Market Knowledge Competence on New Product Advantage: Conceptualization and Empirical Examination. Journal of Marketing, 62(4), 13-29.

Lovelock, H., \& Wright, L. (2001). Principles of Service Marketing and Management, Prentice Hall.

Maleyeff, J. (2006). Exploration of Internal Service Systems Using Lean Principles. Management Decision, 44(5), 674-689.

Mcgill, M. E., \& Slocum, J. W. (1993). Unlearning the Organization. Organisational Dynamics, 22(2), 67-79.

Mikolon, S., Kolberg, A., Haumann, T., \& Wieseke, J. (2015). The Complex Role of Complexity: how Service Providers can Mitigate Negative Effects of Perceived Service 
DOI: $10.14807 /$ ijmp.v12i4.1332

Complexity when Selling Professional Services. Journal of Service Research, 18(4), 513528.

Mithas, S., Krishnan, M. S., \& Fornell, C. (2005). Why do Customer Relationship Management Applications Affect Customer Satisfaction? Journal of Marketing, 69(4), 201209.

Monden, Y. (1983). The Toyota Production System, Productivity Press, Portland, OR.

Ohno, T. (1988). The Toyota Production System: Beyond Large-Scale Production, Productivity Press, Portland, OR.

Paciarotti, C., Ciatteo, V., \& Giacchetta, G. (2011). Value Stream Mapping Implementation in the Third Sector. Operations Management Research, 4(3/4), 99-110.

Ray, S., \& John, B. (2011). Lean Six-Sigma Application in Business Process Outsourced Organization. International Journal of Lean Six Sigma, 2(4), 371-380.

Rich, M. K. (2000). The Direction of Marketing Relationships. Journal of Business \& Industrial Marketing, 15(2/3), 170-179.

Senge, P. (1990). The Fifth Discipline, New York, NY, Currency Doubleday.

Shingo, S. (1981). Study of the Toyota Production Systems, Japan Management Association, Tokyo.

Shou, W., Wang, J., Wu, P., Wang, X., \& Chong, H. (2017). A Cross-Sector Review on the Use of Value Stream Mapping. International Journal of Production Research, 55(13), 3906-3928.

Singh, B., Garg, S. K., \& Sharma, S. K. (2010). Value Stream Mapping: Literature Review and Implications for Indian Industry. The International Journal of Advanced Manufacturing Technology, 53(5-8), 799- 809.

Thomas, A. (2018). Developing an integrated quality network for lean operations systems. Business Process Management Journal, 24(6), 1367-1380.

Ulaga, W., \& Eggert, A. (2006). Value-based Differentiation in Business Relationships: Gaining and Sustaining key Suplier’s Status. Journal of Marketing, 70, 119-136.

Womack, J. P., \& Jones, D. T. (1996). Lean Thinking - Banish Waste and Create Wealth in your Corporation, New York: Free Press.

Woo, K. S., \& Ennew, C. T. (2004). Business-to-Business Relationship Quality: An IMP Interaction-Based Conceptualization and Measurement. European Journal of Marketing, 38(9/10), 1252-1271.

Wu, S. T. P. (2014). The Impact of Customer Knowledge and Customer Relationship Management on Service Quality. International Journal of Quality and Service Sciences, 6(1), 77-96.

Wynstra, F., Axelsson, B., \& Van Der Valk, W. (2006). An Application-Based Classification to Understand Buyer Supplier Interaction in Business Services. International Journal of Service Industry Management, 17(5), 474-496.

Xu, M., \& Walton, J. (2005). Gaining Customer Knowledge Through Analytical CRM. Industrial Management \& Data Systems, 105(7), 955-971.

Zelt, S., Schmiedel, T., \& Vom Brocke, J. (2018). Understanding the nature of processes: an information processing perspective. Business Process Management Journa, 24(1), 67-88. 
DOI: 10.14807/ijmp.v12i4.1332

Zolkiewski J., Story, V., Burton, J., Chan, P., Gomes, A., Hunter-Jones, P., O’malley, L., Peters, L. D., Raddats, C., \& Robinson, W. (2017). Strategic B2B Customer Experience Management: the Importance of Outcomes-Based Measures. Journal of Services Marketing, 31(2), 172-184.

Zoltners, A. A., Sinha, P., \& Lorimer, S. E. (2008). Sales Force Effectiveness: A Framework for Researchers and Practitioners. The Journal of Personal Selling and Sales Management, 28(2), 115-131. 